\title{
Comparison of adolescent's values: Riga and Vidzeme region
}

\author{
Sandra Mihailova ${ }^{1}$, Kristine Martinsone ${ }^{2}$, and Arta Pipcane $^{3}$ \\ ${ }^{1}$ Rīga Stradiņš University, Department of Sociology and Psychology, Riga, Latvia \\ ${ }^{2}$ Rìga Stradinsš University, Department of Health Psychology and Paedagogy, Riga, Latvia \\ ${ }^{3}$ Riga State German Grammar School, Riga, Latvia
}

\begin{abstract}
The determination of individual values is the first step in the process of the personal development. Thus, the main purpose of this research is to investigate the difference between value hierarchies of Riga students and rural students and their subjective opinions about factors affecting them and compare the results with the values of previous generations. It is a pilot study with a comparative cross-sectional design. The study was carried out in several schools of Latvia in 2018: 2 schools of Riga and 2 rural schools of Vidzeme region. Participants were 11th and 12th grade students: 50 from Riga, 50 from rural schools. The research of values was based on the M. Rokeach value ranking test. It is found that the individual hierarchies of values in one group context differ more than hierarchies of adolescent groups of various years and different backgrounds. There are no significant differences related to the terminal and instrumental values between adolescents of Riga and rural areas: love, cheerfulness and education are more important for Riga students, but rural students prefer responsibility, obedience, capability. Some values have not been influenced by time or socio-economic and political situation, but some values have increased or decreased their significance with years.
\end{abstract}

Key words: terminal values, instrumental values, high school students, comparison of generations, i-generation, adolescents.

\section{Introduction}

Researchers have been interested in the exploration of adolescent values at all times. Several researchers have turned to research individuals values (in Latvia - Pauls Dāle, Pauls Jurevičs, Jūlijs Aleksandrs Students, Augusts Milts, Skaidrīte Lasmane, Andris Rubenis, Ārija Karpova, Ilze Koroļeva, Ritma Rungule, Viesturs Reņgée, Silva Seņkāne, Spodra Austruma, Airisa Šteinberga, Ineta Tunne, Ivars Austers u.c.).

The topicality of this research was determined by the socio-economic and political situation in modern Latvia and the changes that have impacted Latvian society in the past 30 years. The regaining of Latvia's independence and the building of a new country, joining European Union, world's integration and globalization processes, the rapid increase of digitalization impact on several social processes as well as each human's world views, stereotypes, values and statuses, and possibilities.

During the recent acceleration of development at significant areas of life, there are radical changes at human relationships, world perception, goals and ideals of life. The revaluation of values as a logical result of human dialectics is controversial and at present it takes place throughout society. New conditions set new requirements for intellectual, mentally rich, open-minded people who are able to adapt to different circumstances, change occupations, 
communicate with different types of people. The determination of individual values is the first step in the process of the personal development. To achieve it, one needs to understand its interests, opinions and priorities and evaluate their significance and hierarchy.

As digitalization becomes part of all areas of life, the widening of the view of the world gives adolescents significantly more opportunities. The way of how these opportunities will be fulfilled is dependent on each youngster's values and choices. With the change of circumstances comes the change of values; time is needed to understand which values fit the new situation, which will have to change and which stay the same.

Furthermore, adolescents have to adapt to new values, arranging points of view and sometimes even own life. Even though there are strict core values at the age of adolescence that have formed based on previous experiences or family values, they can be changed in the course of strong social impact. Adolescents are the social group that adapts more easily on one hand, but on the other - are more easily subjected to media news and social impacts.

The beginning of the highest level of self-confidence development is at the age of 16-19. Though the hierarchy of values is not stable, the main values of young people have been already formed, based on their experience and the values of their parents.

As showed the research of values in 2008, a whole of values is made different by place of residence; there is a significant difference in the values between the young people of city and rural regions [1]. Based on this research, there was a question whether there still is a difference, since social media has an impact on both city and rural areas, and if so, then which values differ.

The high school students of today were born at the turn of 20th and 21st centuries and started their studies when Latvia was already a member of EU. Consequently, they began to attend school when the values of EU had become popular.

These young people have grown up along with the development of Latvia, included in EU unlike the previous high school students. Therefore, it is interesting to explore the possible differences in adolescent's values of previous years and nowadays (among the high school students of 1998 and 2010). After some time, they will develop their own approach and develop the country according to their values. Therefore, it is important to study the values just of high school students to correct them if it is necessary.

Nowadays, there are a lot of discussions around the new "I-generation", which also includes current high school students. Are the values of this new generation drastically different from those of previous generations? This is the question to answer in this research. The objective was - to find out the difference between value hierarchies of Riga students and rural students and their subjective opinions about factors affecting them, and compare the results with the values of previous generations. Research issues: What is the hierarchy of values among adolescents? What is the difference between the value scales of Riga and rural areas? What is the difference between the values of adolescents in 2018 and the ones of previous years?

\section{Values as a basic concept of the study}

As it was mentioned in the introduction of this article, the values have been studied quite a lot in various fields of science, especially in the second half of the 20th century [2-7]. However, the sciences appreciate different values - the definitions of values differ in psychology, philosophy and sociology, so there are no common definitions and approaches. It has always been a topical issue about the way how other people influence on the value system of the person. A unified vision of values was formed only after the work of American social psychologist Milton Rokeach was published $[8,9]$ that strongly influenced further research 
of values. Nowadays Rokeach methodology is used as a tool for value research in several fields of science - psychology, sociology and marketing as well. Several authors developed their tools of value research based on his methodology [10,11].

This research also is based on the value theory of Rokeach. Rokeach defines a value as long-term confidence of an individual, that a specific mode or state of existence is more acceptable than the other modes or states for this individual and the society as well [9].

According Rokeach, the value system consists of two main groups - terminal values and instrumental values. He defines terminal values as the individual's confidence in life and the desired end state of existence that the individual tries to achieve during his life. Whereas he defines the instrumental values as the principles/opinions (such as honesty and courage) that are used to achieve the desired life goals, i.e. terminal values [9]. This approach was supported and also criticized widely by several scientists [12-18]. Richard Gorsuch was critical about the breakdown of values claiming that any value can be supposed as instrumental value if the terminal value is not absolute [12]. Shalom H. Schwartz considered that the breakdown made by Rokeach is not significant, because it makes the value system too narrow and limited [14]. Unlike Schwartz's theory that included 57 values which were divided in 10 universal core value groups, Rokeach used only 36 values; and high school students filled the Rokeach's questionnaire more gladly than the Schwartz's as the author of the article has observed. Therefore, in author's opinion the Rokeach's value questionnaire is more appropriate and more often used at the research of adolescent's values.

Generally, the value system is influenced by many factors: family, society, media and authorities, various political and socio-economic conditions [1], so it is difficult to estimate which impact is more or less significant. Young people are particularly sensitive to the impact of various external factors and social pressures, because they try to find the balance between the internal and external values, they try to set their future goals and make plans [19]. Young people are the most studied group, moreover the comparative study of different groups of young people have become even more popular in $21^{\text {st }}$ century [20-22]. Therefore, this research compares adolescents of different times and looks for the answer to the question: which values are influenced and which remain unchanged in the value hierarchy of adolescents in the context of time and their background.

\section{Material and methods}

It is a pilot study with a comparative cross-sectional design. The research of values was based on the Rokeach value ranking test. 100 adolescents at the age of 16-18 were selected as respondents for the quantitative survey $\left(10^{\text {th }}\right.$ to $12^{\text {th }}$ grade students of 2018) from two different backgrounds, 50 from each: students from Latvian schools of Riga (hereinafter called group "Riga") and students from rural schools (hereinafter called group "Rural"). The study was carried out in several schools of Latvia in 2018: 2 schools of Riga and 2 rural schools of Vidzeme region. Participants were 11th and 12th grade students, 25 from each school, 50 of them were from Riga and 50 from rural schools.

These data were compared with the selected data about 74 high school students that were collected in 2010, and the data about 110 high school students that were collected in 1998. Accordingly, there was obtained the information about the impact of various economic, political and social factors on young people values.

All groups of respondents included boys and girls, but their proportion was not stated, because it was not planned to study differences by gender. The statistical analysis of data was carried out using SPSS program and the values were compared using the Mann-Whitney U test and Kruskal-Wallis Z test. 
Table 1. Comparison of terminal values of adolescent groups in 2018 according Mann-Whitney test.

\begin{tabular}{|l|c|c|c|c|}
\hline Type of value & \multicolumn{2}{|c|}{ Mdn $(\mathbf{I Q R})$} & \multicolumn{2}{c|}{ Mann-Whitney test } \\
\hline Terminal values & 2018-Riga1 & $\mathbf{2 0 1 8 - R u r a l ~}$ & $z$ & $\boldsymbol{p}$ \\
\hline Active life & $7(5-11)$ & $7(4-12)$ & -1.363 & 0.173 \\
\hline Wisdom of life & $8(4-11)$ & $7(4-12)$ & -0.097 & 0.923 \\
\hline Physical and mental health & $4(2-8)$ & $4(2-6)$ & -0.177 & 0.860 \\
\hline Interesting job & $11(8-14)$ & $11(7-14)$ & -0.062 & 0.950 \\
\hline Beauty of nature and art & $16(13-17)$ & $16(13-18)$ & -1.090 & 0.267 \\
\hline Love & $3(2-5)$ & $5(2-10)$ & -2.043 & 0.016 \\
\hline Comfortable life & $11(4-14)$ & $9(5-13)$ & -0.377 & 0.707 \\
\hline Good and true friends & $6(4-8)$ & $7(4-11)$ & -1.193 & 0.233 \\
\hline Public appreciation and respect & $15(12-16)$ & $14(9-16)$ & -1.265 & 0.206 \\
\hline Cognition & $12(7-15)$ & $10(6-13)$ & -1.652 & 0.099 \\
\hline Productive life & $9(5-12)$ & $10(7-13)$ & -1.244 & 0.213 \\
\hline Development & $8(6-12)$ & $8(4-11)$ & -0.066 & 0.948 \\
\hline Life rich in enjoyment and fun & $15(8-18)$ & $15(10-16)$ & -0.108 & 0.914 \\
\hline Freedom & $8(5-10)$ & $9(5-11)$ & -0.668 & 0.504 \\
\hline Happy family life & $2(1-6)$ & $3(1-8)$ & -1.040 & 0.298 \\
\hline Happiness of other people & $15(13-17)$ & $15(11-17)$ & -0.392 & 0.695 \\
\hline Creativity & $15(11-17)$ & $13(9-16)$ & -1.280 & 0.200 \\
\hline Self-confidence & $9(6-14)$ & $10(5-13)$ & -0.539 & 0.590 \\
\hline
\end{tabular}

The Latvian version of Rokeach Value Survey was used to perform the analysis of quantitative data (Rokeach Value Survey [9], it was adapted in Latvian by Karpova in 1994 [23]) that consisted of two parts: terminal and instrumental values. Each part included 18 values that students had to arrange according to their subjective importance and estimate (in percentage) how much this value has already been realized. Finally, each value got its position in the hierarchy. Rokeach Value Survey was used also in the researches of 1998 and 2010, so the results are comparable.

In the beginning the terminal and instrumental values were compared between both respondent groups of 2018. The statistical non-parametric Mann-Whitney test was used to find which terminal or instrumental values are statistically significant (Tables 1 and 2).

\section{Results and discussion}

\subsection{Comparison of terminal and instrumental values of adolescent groups in 2018}

Mann-Whitney test (Table 1) showed that the only statistically significant difference between adolescents of Riga and Rural groups is according the value "love" $(z=-2.043, p=0.016)$. It means that "love" (as mental and physical intimacy with the beloved person) is more important value for adolescents of Riga than for rural adolescents. All other values are equally important for all adolescents in 2018, regardless of where they live.

Three most important terminal values for both Riga and rural students from high schools are "happy family life", "physical and mental health" and "love" (Riga students preferred "love" to "health", but rural students had the opposite opinion). The less important values appeared to be "happiness of other people" and "beauty of nature and art". 
Table 2. Comparison of instrumental values between Riga and Rural students in 2018 according Mann-Whitney test.

\begin{tabular}{|l|c|c|c|c|}
\hline Type of value & \multicolumn{2}{|c|}{ Mdn (IQR) } & \multicolumn{2}{c|}{ Mann-Whitney test } \\
\hline Instrumental values & $\mathbf{2 0 1 8 - R \overline { g a ~ }}$ & $\mathbf{2 0 1 8 - l a u k i}$ & $\boldsymbol{z}$ & $\boldsymbol{p}$ \\
\hline accuracy & $11(6-14)$ & $11(6-13)$ & -0.080 & 0.937 \\
\hline upbringing & $6(4-11)$ & $5(2-9)$ & -1.960 & 0.050 \\
\hline high claims & $14(10-17)$ & $15(12-17)$ & -1.206 & 0.228 \\
\hline joy of life and sense of humour & $5(2-8)$ & $8(5-12)$ & -2.691 & 0.007 \\
\hline conscientiousness & $12(7-15)$ & $8(6-12)$ & -2.334 & 0.020 \\
\hline independence & $8(3-13)$ & $9(5-13$ & -0.954 & 0.340 \\
\hline $\begin{array}{l}\text { intolerance towards their own and } \\
\text { other's deficiencies }\end{array}$ & $17(12-18)$ & $17(15-18)$ & -0.038 & 0.969 \\
\hline education & $7(4-9)$ & $10(5-13)$ & -2.518 & 0.012 \\
\hline reliability & $9(4-12)$ & $4(3-9)$ & -2.461 & 0.014 \\
\hline rationalism & $10(5-12)$ & $10(5-16)$ & -1.434 & 0.152 \\
\hline self-control & $8(5-12)$ & $9(3-14)$ & -0.262 & 0.793 \\
\hline courage & $13(8-15)$ & $12(6-14)$ & -0.641 & 0.522 \\
\hline strong will & $7(3-13)$ & $8(4-12)$ & -0.159 & 0.874 \\
\hline patience & $6(8-12)$ & $9(5-11)$ & -0.263 & 0.793 \\
\hline breadth of views & $10(5-14)$ & $11(7-15)$ & -0.594 & 0.552 \\
\hline honesty & $6(1-12)$ & $6(2-11)$ & -0.007 & 0.994 \\
\hline efficiency at work & $11(8-14)$ & $10(7-13)$ & -0.657 & 0.511 \\
\hline responsiveness, ingenuity & $10(5-15)$ & $8(5-11)$ & -1.368 & 0.171 \\
\hline
\end{tabular}

Mann-Whitney test showed (Table 2) that the statistically significant differences between adolescents of Riga and Rural groups are only according following values: "upbringing" ( $z=-1.960, p=0.050)$, "joy of life and sense of humour" $(z=-2.691$, $p=0.007)$, "conscientiousness" $(z=-2.334, p=0.020)$, "education" $(z=-2.518, p=$ $0.012)$, "reliability" $(z=-2.461, p=0.014)$. It means that "joy of life" and "education" are more important values for adolescents of Riga than it is for rural adolescents. In turn rural adolescents appreciate "upbringing", "conscientiousness" and "reliability" higher than adolescents of Riga. All other values are equally important for all adolescents in 2018, regardless of where they live.

\section{Comparison of terminal values of $11^{\text {th }}$ and $12^{\text {th }}$ grade students by years}

As the previous research of values was carried out with $11^{\text {th }}$ and $12^{\text {th }}$ grade students from Riga and rural regions, also comparison of terminal values by years regarding 2018 was represented by joint group "2018" that includes adolescents from group "Riga" and group "Rural". The Kruskal-Wallis rank test (Table 3) was performed to check if there are statistically significant differences between terminal values of Latvian adolescents of Riga in 1998, 2010 and 2018.

Kruskal-Wallis test shows that the statistically significant differences between all groups are regarding only following values: "Wisdom of life", "Interesting job", "Comfortable life", "Public appreciation and respect" (from surrounding people, school mates), "Life rich in 
Table 3. Comparison of terminal values by years according Kruskal-Wallis test.

\begin{tabular}{|l|c|c|c|c|c|}
\hline Type of value & \multicolumn{3}{|c|}{ Mdn $(\mathbf{I Q R})$} & Kruskal-Wallis test \\
\hline Terminal values & $\mathbf{1 9 9 8}$ & $\mathbf{2 0 1 0}$ & $\mathbf{2 0 1 8}$ & $\chi^{2}$ & $\boldsymbol{p}$ \\
\hline Active life & $8(5-11)$ & $8(5-12)$ & $7(5-11)$ & 1.135 & 0.567 \\
\hline Wisdom of life & $10(5-13)$ & $9(4-13)$ & $8(4-11)$ & 8.043 & 0.018 \\
\hline Physical and mental health & $5(2-10)$ & $5(2-9)$ & $4(2-8)$ & 1.508 & 0.471 \\
\hline Interesting job & $8(5-11)$ & $9(5-12)$ & $11(8-14)$ & 16.378 & 0.000 \\
\hline Beauty of nature and art & $16(14-17)$ & $14(10-17)$ & $16(13-17)$ & 8.908 & 0.012 \\
\hline Love & $4(2-7)$ & $4(2-8)$ & $3(2-5)$ & 0.953 & 0.621 \\
\hline Comfortable life & $6(3-11)$ & $7(4-13)$ & $11(4-14)$ & 7.837 & 0.020 \\
\hline Good and true friends & $4(3-7)$ & $7(4-12)$ & $6(4-8)$ & 17.421 & 0.000 \\
\hline Public appreciation and respect & $9(6-13)$ & $12(8-15)$ & $15(12-16)$ & 33.827 & 0.000 \\
\hline Cognition & $10(6-12)$ & $11(7-14)$ & $12(7-15)$ & 3.743 & 0.154 \\
\hline Productive life & $11(6-14)$ & $9(6-13)$ & $9(5-12)$ & 1.802 & 0.406 \\
\hline Development & $8(5-11)$ & $8(5-12)$ & $8(6-12)$ & 0.343 & 0.843 \\
\hline Life rich in enjoyment & $16(12-18)$ & $11(7-16)$ & $15(8-18)$ & 16.417 & 0.000 \\
\hline Freedom & $9(5-12)$ & $9(5-14)$ & $8(5-10)$ & 0.869 & 0.648 \\
\hline Happy family life & $6(3-13)$ & $9(3-14)$ & $2(1-6)$ & 40.459 & 0.000 \\
\hline Happiness of other people & $15(13-17)$ & $15(11-17)$ & $15(13-17)$ & 0.744 & 0.689 \\
\hline Creativity & $15(11-17)$ & $14(8-17)$ & $15(11-17)$ & 3.939 & 0.149 \\
\hline Self-confidence & $9(5-13)$ & $10(6-14)$ & $9(6-14)$ & 1.048 & 0.586 \\
\hline
\end{tabular}

enjoyment and fun" (life without duties), "Happy family life", "Beauty of nature and art" (enjoying it), "Good and true friends".

Comparing groups of respondents in pairs (Mann-Whitney test) it was found that there are statistically significant differences between the results of 2018 and 2010 regarding following values: "Interesting job" $(z=-2.356, p=0.018)$, "Beauty of nature and art" $(z=-2.411, p=0.016)$, "Public appreciation and respect" $(z=-2.729, p=0.006)$, "Life rich in enjoyment and fun" $(z=-2.349, p=0.019)$ and "Happy family life" $(z=-5.183$, $p=0.000)$.

It means that such values as "Interesting job", "Beauty of nature and art", "Public appreciation and respect" and "Life rich in enjoyment and fun" have become less important for adolescents in 2018 than it was for adolescents in 2010, though the importance of the value "Happy family life" has increased.

There are following statistically significant differences between the indicators of the value importance in 2018 and 1998: "Wisdom of life" $(z=-2.906, p=0.004)$, "Interesting job" $(z=-4.062, p=0.000)$, "Comfortable life" $(z=-2.768, p=0.006)$, "Good and true friends" $(z=-2.857, p=0.004)$, "Public appreciation and respect" $(z=-5.728$, $p=0.000)$ and "Happy family life" $(z=-5.698, p=0.000)$.

It proves that such values as "Wisdom of life" and "Happy family life" are more important for adolescents of 2018 than for adolescents of 1998. Whereas the values "Interesting job", "Comfortable life", "Good and true friends" and "Public appreciation and respect" seem less important than they were in 1998.

It means that comparing with the values of adolescents of 1998 and 2010 the only value, that has become more important for adolescents of 2018, is "Happy family life", but the values "Interesting job" and "Public appreciation and respect" have lost their position. 
During studies of value changes of 1998, it was stated in 2015 [24] that such values of adolescents of 1998 as "Family" and "Job" have become more important in 2015, but the value "Friends" has lost its importance. It means that during 20 years the value "Family" has become more important for the new generation of high school students and for the dynamics of values of one generation as well.

Comparing the obtained data with the data of the 2015 study [25], when the data of 1998 were compared with the data of 2005, 2010 and 2015, it is evident that the value "Wisdom of life" in 1998 was of less importance than it was in 2015 and 2018, but it was as important as in 2005 and 2010. So, the attitude of young people has changed after 2010.

On the other hand, the dynamics in relation to the value "Interesting job" is reversed - it has become less important for adolescents after 2010. The banking crisis in 1995, and then the economic crisis in 2008 made many people feel threatened with losing their jobs - so the value "Interesting job" was important for young people in 1998 and 2010 as well. When the situation returned to normal, the importance of the value "Interesting job" decreased in 2018. As to the values "Good and true friends", "Public appreciation and respect" and "Productive life" - they have become less important since 2005.

The value "Life rich in enjoyment and fun" was on less importance in 1998 than it was in 2015, but it was the same as in 2018. Thus, it can be assumed that the importance of this value increased from 1998 to 2010 and after that it decreased gradually, in 2018 reaching the level of 1998. But the value "Happy family life" has the opposite dynamics - it loses its significance in the period of 2005-2010, and after that regains it gradually becoming much more important for adolescents in 2018 than in 1998. As for "Freedom", it becomes more important for young people in 2015, but in 2018 it returns to the level of previous years.

There are statistically significant differences between the groups of 1998 and 2010 regarding following values: "Beauty of nature and art" $(z=-2.851, p=0.004)$, "Good and true friends" $(z=-3.947, p=0.000)$, "Public appreciation and respect" $(z=-2.786$, $p=0.005)$, "Life rich in enjoyment and fun" $(z=-3.996 p=0.000)$. In addition the value "Public appreciation and respect" has become less important in 2010 and gradually loses its position in 2018 ( it takes $6^{\text {th }}-13^{\text {th }}$ place of the individual hierarchies in $1998,8^{\text {th }}-15^{\text {th }}$ place in 2010 and $12^{\text {th }}-16^{\text {th }}$ place in 2018). The other values do not show such dynamics. It is possible that this value has lost its significance because of the development of social network that may have created certain "immunity" to public appreciation.

On the other hand, the values "Active life", "Physical and mental health", "Cognition" (possibility to expand horizons, education, and cultural level), "Productive life" (maximum use of abilities, strengths and capabilities, "Development" (working with yourself, constant physical and mental development), "Freedom" (independence in thinking and judgment), "Happiness of other people" (welfare of other people, the whole nation), "Creativity" (creative work opportunity) and "Self-confidence" (internal harmony, the removal of internal contradictions and doubts) are equally significant for all young people in 1998, 2010 and 2018 .

But the values "Health", "Productive life", "Development", "Freedom", "Other people happiness" and "Creativity" are equally important for all adolescents in 1998, 2010 and 2018, regardless of where they live - in Riga or in the countryside. It means the significance of these values is not affected by time and socio-economic-political situation. When analysing individual value hierarchy, it can be noticed that the value "Health" takes $1^{\text {st }}$ to $10^{\text {th }}$ place, "Productive life" $-5^{\text {th }}$ to $14^{\text {th }}$ place, "Development" $-4^{\text {th }}$ to $12^{\text {th }}$ place, "Freedom" $-4^{\text {th }}$ to $14^{\text {th }}$ place, "Happiness of other people" $-11^{\text {th }}$ to $17^{\text {th }}$ place and "Creativity" $-8^{\text {th }}$ to 17 th place. It means that in terms of value importance, individual differences are greater than the differences between different groups of young people of different years. 
Table 4. Comparison of instrumental values by years according Kruskal-Wallis criterion.

\begin{tabular}{|l|c|c|c|c|c|}
\hline Type of value & \multicolumn{3}{|c|}{ Mdn (IQR) } & \multicolumn{2}{c|}{ Kruskal-Wallis test } \\
\hline Instrumental values & $\mathbf{1 9 9 8}$ & $\mathbf{2 0 1 0}$ & $\mathbf{2 0 1 8}$ & $\chi^{2}$ & $\boldsymbol{P}$ \\
\hline accuracy & $9.5(6-14)$ & $10.5(8-15)$ & $11(6-13)$ & 1.451 & 0.484 \\
\hline upbringing & $9(4-12)$ & $9(5.8-14.3)$ & $5(2-10)$ & 13.617 & 0.001 \\
\hline high claims & $16(10.8-17)$ & $15(10-17)$ & $15(11-17)$ & 0.226 & 0.893 \\
\hline joy of life and sense of humour & $7(3-10.3)$ & $5.5(2-12)$ & $6(3-11)$ & 0.203 & 0.904 \\
\hline conscientiousness & $13(9-16)$ & $13.5(9.8-16)$ & $10(6-14)$ & 11.006 & 0.004 \\
\hline independence & $7.5(3-13)$ & $6(3-10.3)$ & $8(4-13)$ & 1.579 & 0.454 \\
\hline $\begin{array}{l}\text { intolerance towards their own and } \\
\text { other's deficiencies }\end{array}$ & $17(14-18)$ & $17(12.8-18)$ & $17(12-18)$ & 4.415 & 0.110 \\
\hline education & & & & & \\
\hline reliability & $6(3-9)$ & $7(3-11)$ & $8(4-12)$ & 10.744 & 0.005 \\
\hline rationalism & $6(3-10.8)$ & $8(5-11.3)$ & $7(3-12)$ & 2.322 & 0.313 \\
\hline self-control & $9(5-13)$ & $9(5-13)$ & $10(5-14)$ & 0.975 & 0.614 \\
\hline courage & $8(4-13)$ & $9(5-13.3)$ & $9(4-13)$ & 1.407 & 0.495 \\
\hline strong will & $10(6-14)$ & $10(4-13)$ & $13(8-14)$ & 5.617 & 0.060 \\
\hline patience & $5(3-9)$ & $5(3-11)$ & $8(4-13)$ & 8.826 & 0.012 \\
\hline breadth of views & $10(5-14)$ & $10(6-13)$ & $8(5-12)$ & 2.536 & 0.281 \\
\hline honesty & $9.5(6-13)$ & $9(4-13)$ & $10(7-14)$ & 2.218 & 0.330 \\
\hline efficiency at work & $6.5(2-11)$ & $7(3-10.3)$ & $6(2-11)$ & 0.323 & 0.851 \\
\hline responsiveness, ingenuity & $13(9-15)$ & $10(5.8-13)$ & $11(8-14)$ & 10.882 & 0.004 \\
\hline & $11.5(8-14)$ & $9(7-14)$ & $9(5-14)$ & 8.000 & 0.018 \\
\hline
\end{tabular}

\section{Comparison of instrumental values of $11^{\text {th }}$ and $12^{\text {th }}$ grade students by years}

The Kruskal-Wallis rank test (Table 4) was performed to check if there are statistically significant differences between instrumental values of Latvian adolescents of Riga in 1998, 2010 and 2018.

In Table 4 it was shown that there are statistically significant differences in all groups only regarding following values: "Upbringing", "Conscientiousness", "Education", "Strong will", "Efficiency at work" and "Responsiveness".

Comparing groups of respondents in pairs (using Mann-Whitney criterion) it was found that there are statistically significant differences between the results of 2018 and 2010 only regarding one value - "Upbringing" $(z=-2.170, p=0.030)$. It means that the value "Upbringing" has become more important for adolescents of 2018 than for adolescents of 2010, and there is no value that is less important than in 2010.

There are statistically significant differences between the indicators of value importance in 2018 and 1998 regarding following values: "Upbringing" $(z=-3.702, p=0.000)$, "Conscientiousness" $(z=-3.350, p=0.001)$, "Education" $(z=-3.004, p=0.003)$, "Courage" ( $z=-2.418, p=0.016)$, "Strong will" $(z=-2.689, p=0.004)$, "Efficiency at work" $(z=-2.539, p=0.011)$ and "Responsiveness" $(z=-2.563, p=0.010)$.

It means that the values "Upbringing", "Conscientiousness", "Efficiency at work" and "Responsiveness" are supposed more important for adolescents of 2018 than for adolescents of 1998. On the other hand, the values "Education", "Courage", "Strong will" seem to be less important than in 1998. 
Table 5. Main terminal values and their positions in the value hierarchy in different groups of respondents.

\begin{tabular}{|l|l|l|l|l|l|}
\hline Group & 1st place & 2nd place & 3rd place & 4th place & 5th place \\
\hline 1998 & Love & Friends & Health & Happy Family & Happy family \\
\hline 2010 & Love & Health & Friends & Comfortable life & Development \\
\hline 2018 (total) & Happy family & Health & Love & Friends & Active life \\
\hline 2018-Rīga1 & Happy family & Health & Love & Friends & Active life \\
\hline 2018- Rural & Happy family & Health & Love & Active life/ Wisdom of life & Development \\
\hline
\end{tabular}

It follows from the above that the only value that has become more important for young people in 2018 compared to both young people in 2010 and 1998 is "Upbringing".

Both groups point out "reliable friends" as the most accomplished value. Adolescents of both groups note that their values are most influenced by family and school; while in the third-place rural youth mention opinion leaders, but youth from Riga - social media.

The opinions of adolescents and experts about the values important to youth differ, but they rank the value-influencing agents similarly. There is diversity among expert opinions about the values and their hierarchy that are topical to the youth that could be explained as manifestation of generation gap. Experts highlight the value "material well-being" as the most important for adolescents and emphasize the impact of social media on its development.

\subsection{Changes in the hierarchy of terminal and instrumental values over the years}

If we look at the main terminal values of all groups (Table 5), it is evident that the leading five values in 1998 are as follows: "Love", "Friends", "Health", "Comfortable life" and "Happy family life".

This tendency was identified also during the studies in 1998, 2005 and 2010. These values are also mentioned as leading in the author's research performed among high school students [25-30], among university students [31] and also at transnational studies [32]. These data also coincide with the research carried out with university students by Professor of psychology Ārija Karpova [23]. Similar results were obtained by Spodra Austruma in her promotion work about young people values in consumer society, where it was stated that dominant values are "Family", "Friends", "Health", "Education", "Love", "Career" and "Freedom" [33].

According to the data of this research "Happy family" is replaced by "Development" in 2010; but "Comfortable life" is replaced by "Active life" in 2018. In addition, "Happy family life" rivals "Friends" and "Comfortable life" in the hierarchy of adolescents of 2018. Apart from this, "Wisdom of life" for rural adolescents and "Self-confidence" for Russian speaking adolescents have achieved unusually high ranking in the hierarchy. These results may be explained by the background differences. To survive in the rural area people rely more on knowledge accumulated in their lives and from their ancestors; so this can be also called "Wisdom of life", but there are no statistically significant differences.

At the request of the Ministry of Education and Science, Excolo Latvia Ltd performed a study on the values of young people in Latvia in 2012-2013 and found following significant values of young people: "Domesticity", "Stable job", "Interesting job", "Happy life with the partner", "Well paid occupation", "Good education" and "Ability to provide a safe future for their children". On the other hand, such values as "Interest about politics", "Doing something for the public good" and "Learning about other cultures" were appreciated much less [34]. 
Table 6. Main instrumental values and their positions in value hierarchy of different respondent groups.

\begin{tabular}{|l|l|l|l|l|c|}
\hline Group & 1st place & 2nd place & 3rd place & 4th place & 5th place \\
\hline 1998 & Imagination & Intellect & Responsibility & Honesty & Cheerfulness \\
\hline 2010 & Imagination & $\begin{array}{l}\text { Cheerfulness } \\
\text { Independence }\end{array}$ & Honesty & Intellect & responsibility \\
\hline 2018 (total) & Obedience & Honesty & Cheerfulness & Responsibility & Imagination \\
\hline 2018-Rīga1 & Cheerfulness & Honesty & Obedience & Intellect & Independence \\
\hline 2018- Rural & Obedience & Responsibility & Honesty & Strong will & Helpfulness \\
\hline
\end{tabular}

The values related to work and money do not rank high in the hierarchy, but "Work for others" ("Welfare of others" in this research) is one of the less important values in all respondent groups during 20 years.

This study shows only trends of changes in values of high school students during the last 20 years both in cross-sectional and longitudinal terms. The degree of impact of media, economic and political situation, digitization and globalization processes on the dynamics of these changes in values have to be studied in the future research. It would be worth exploring the media of young people of the related years, the changes in main messages in them and performing the qualitative study of young people values.

\section{Conclusions}

Individual hierarchies of values in one group context differ more than hierarchies of adolescent groups of various years and different backgrounds. There are no significant differences related to the terminal and instrumental values between adolescents of Riga and rural areas. Therefore, it can be concluded that there is no significant differences whether to study the values of adolescents in Riga or in rural areas.

Some values ("Health", "Productive life", "Development", "Freedom", "Happiness of other people" and "Creativity") have not been influenced by time or socio-economic and political situation, but there are also values with changing significance that increases ("Happy family life") or decreases ("Interesting job", "Public appreciation and respect") with years: Values "Active life", "Cognition" and "Self-confidence" are equally significant for all Latvian speaking adolescents in 1998, 2010 and 2018; "Happy family life" is the only value that has become more important for adolescents of 2018 comparing with adolescents of 2010 and 1998. On the other hand, adolescents of 2018 estimate such values as "Interesting job" and "Public appreciation and respect" as less important; Value "Public appreciation and respect" has become less important in 2010 and even much less important in 2018, comparing with 1998. Adolescents of 2018 estimate "Wisdom of life" and "Happy family life" higher than adolescents of 1998, but they underestimate such values as "Interesting job", "Comfortable life", "Good and true friends" and "Public appreciation and respect"; Values "Interesting job", "Beauty of nature and art", "Public appreciation and respect" and "Life rich in enjoyment and fun" have become less important for adolescents of 2018, but "Happy family life" has become much more important comparing with 2010.

Comparing the significance of the values of Riga and rural students we found out that love, cheerfulness and education are more important for Riga students, but rural students prefer responsibility, obedience and capability. The greatest difference in instrumental values is between 1998, 2010 and 2018, not between 2010 and 2018. "Wisdom" and "Strong will" were more important in 1998 compared with 2010 and 2018. "Obedience" is more important 
in 2018, compared with 2010 and 1998. "Happiness of other people" is the only value whose importance has not changed in the period of 20 years. Values "Wisdom of life", "Interesting job", "Comfortable life", "Public appreciation and respect" and "Life rich in enjoyment and fun" are equally important for all adolescents of 2018, regardless of where they live, but their importance was different for adolescents of previous years.

"Love", "Friends" and "Health" took first places in the hierarchy of terminal values, by 2010 . But the value "Happy family life" competes with "True friends" and "Health" in the hierarchy of adolescents of 2018 and gets the first place among the selection of Latvian students. Young people aged 17-19 prioritize classical or terminal values (family, love, health), however there are slight differences between Vidzeme region and Riga city.

\section{References}

[1] I. Koroieva, Jauniešu vērtības un nākotnes plāni. Latvijas jaunatnes portrets: integrācija sabiedrībā un marginalizācijas riski. Rīga: LU Akadēmiskais apgāds, 189-210, 1pp (2009)

[2] C.K.M. Kluckhohn, Values and value orientations in the theory of action. In T. Parsons, E. Shils (Ed.), Towarda General Theory of Action (Cambridge, MA, Harvard University Press, 1951), pp. 388-433

[3] D. Katz, E. Stotland, A preliminary statement to a theory of attitude structure and change. In S. Koch (Ed.), Psychology: A Study of a Science (New York, McGraw-Hill, 1959), pp. 423-475

[4] G.W. Allport, P.E. Vernon, G. Lindzey, Astudy of Values (Boston, Houghton, Mifflin Co. 1960)

[5] M.B. Smith, Personal values in the study of lives. In R. W. White (Ed.). The Study of Lives (Atherton Press, New York, 1963), pp. 324-347

[6] H. Fallding, A proposal for the empirical study of values Am. Sociological Rev. 30, 223-233 (1965)

[7] R.M. Williams, The concept of values. In E. Sills (Ed.) International Encyclopedia of the Social Sciences (New York, Macmillan, 1968), pp. 283-287

[8] M. Rokeach, Beliefs, Attitudes and Values (San Francisko, Jossey-Bass, 1968)

[9] M. Rokeach, The Nature of Human Values (Free Press, New York, 1973)

[10] S.H. Schwartz, Universals in the content and structure of values: Theoretical advances and empirical tests in 20 countries. In M.P. Zanna (Ed.) Advances in Experimental Sochology. Vol. 25 (San Diego, Academic Press, 1992), pp. 1-65

[11] Е.Б. Фанталова, Об одном методическом подходе к исследованию мотивации и внутренних конфликтов. Психологический журнал. Т.13., н1, c. $107-117(1992)$

[12] R.L. Gorsuch, R.L. Rokeach's approach to value systems and social compassion. Rev. Religious Res. 11, 139-143 (1970)

[13] R. Lynn, Review of "The nature of human values" by M. Rokeach. Br. J. Psychol. 65, 453 (1974)

[14] S. Schwartz, Review: A Survey of Guiding Principles. Reviewed work(s): The Nature of Human Values by Milton Rokeach. In Sci. New Ser. 186(4162), 436-437 (1974)

[15] D.M. Keats, J.A. Keats, Review of "The nature of human values" by M. Rokeach. Aust. J. Psychol. 26, 164-165 (1974)

[16] T.M. Kitwood, A.G. Smithers, Measurement of human values: An appraital of the work of Milton Rokeach, Educational Res. 17, 175-179 (1975)

[17] R.A. Jones, J. Sensening, R.D. Ashmore, Systems of values and their multidimensional representations, Multivariate Behav. Res. 13, 255-270 (1978) 
[18] V.A. Braithwaite, H.G. Law, Structure of Human Values: Testing the Adequacy of the Rokeach Value Survey. J. Personality and Soc. Psychol. 49(1), 250-263 (1985)

[19] G.J. Craig, Human Development (New Jersey, Prentice Hall, 1996)

[20] S. Karvonena, R. Young, P. West, O. Rahkonen, Value. orientations among late modern youth - a cross-cultural study. J. Youth Stud. 15(1), 33-52 (2012)

[21] N. Gorlova, L. Romanyuk, L. Vanbrabant, R. van de Schoot,. Eur. J. Dev. Psychol. 6, 744-750 (2012)

[22] A. Doring, S. Schwartz, J. Cieciuch, P. Groenen, V. Glatzel, J. Harasimczuk, N. Janowicz, M. Nyagolova, R. Scheefer, M. Allritz, Cross-cultural evidence of value structures and priorities in childhood, Br. J. Psychol. 106(4), 675-699 (2015)

[23] A. Karpova, Personība un Individuālais Stils (Rīga, LU, 1994)

[24] M. Sokola-Nazarenko, K. Martinsone, S. Mihailova, J. Levina, E. Karsa, The Dynamics of Value System in 1998 and 2015: Longitudinal Research in Latvia. $6^{\text {th }}$ International Interdisciplinary Scientific Conference "Society. Health. Welfare". Available at: https://www.shs-conferences.org/articles/shsconf/pdf/ 2018/12/shsconf_shw2016_01008.pdf (2018)

[25] J. Levina, K. Martinsone, S. Mihailova, I. Gintere, Proc. Int. Sci. Conf. 3, 577-587 (2015)

[26] S. Jirgena, Jauniešu pašizjūta un adiktīvas uzvedības izvēele. Promocijas darbs (Latvijas Universitāte. Rīga, 1999) 78 lpp.

[27] S. Jirgena, K. Mārtinsone, Vērtību hierarhija: jauniešu salīdzinošais vērtējums 1998. un 2005. gadā. Sabiedrība un kultūra. Rakstu krājums IX. A. Medveckis (Sast.) (Liepāja, LiePa, 2007, 2007) 112-119 lpp.

[28] С. Йиргена, И.Я. Михайлов, Динамика ценностных ориентаций в структуре личностных характеристик молодёжи Латвии. Межкультурная коммуникация: кониепты и модели поведения. Астрахань: Издательский дом “Астраханский университет”. с. 191-195 (2007)

[29] С. Михайлова, Сотрудничество как ценность: сравнительная оценка латвийской молодёжи в 1998 и 2009 году. Partnerstwo i wspolpraca a kryzys gospodarczo-spoleczny w Europie srodkowej i wschodniej. - Lublin: Wydawnictwo. т.1., c. 607-615 (2010)

[30] S. Mihailova, Динамика ценностей латвийской молодежи во время кризиса. Starptautiskās starpdisciplinārās zinātniskās konferences "Krīze un tās pārvarēšanas iespējas” tē̌̌u krājums. Rīga: RPIVA, RSU, 36-37 lpp. (2011)

[31] S. Mihailova, O. Rasnačs, Vērtību hierarhijas izpēte: Rīgas Stradiòa universitātes 1.kursa dažādu programmu salīdzinošais vērtējums 2010. gadā. RSU 2011.gada zinātniskā konference. Tēzes. (Rīga, Rīgas Stradiòa universitāte, 2011), 409 lpp.

[32] S. Mihailova, V. Perepjolkina, Krievvalodīgo skolēnu vērtības: Baltijas valstu salīdzinājums. RSU 2018.gada zinātniskā konference.Tēzes. Rīga: Rīgas Stradiòa universitāte, 295 lpp. (2018)

[33] S. Austruma, Rēzekne: Rēzeknes Augstskola, Jauniešu vērtības patēēêtāj sabiedrībā Latvijā: Promocijas darbs (2012)

[34] Excolo Latvia Jauniešu iespēju, attieksmju un vērtību pētījums. Available at: http://www.izm.gov.lv/images/statistika/petijumi/23.pdf (2013) 